Mitja Reichenberg

Inštitut in akademija za

multimedije (IAM)

Ljubljana, Slovenija

mitja.reichenberg@gmail.com
DOI:https://doi.org/10.18485/slovenika.2019.5.1.8

UDK: 791.636:78(497.4)

Pregledni članek

\title{
Filmska glasba in zlata leta slovenskega filma (2)
}

Povzetek

Prispevek predstavlja partiture skladatelja Bojana Adamiča, ki so bile namenjene filmskim podobam velikega platna, v drugi vrsti pa opozarja na to, kar slovenska filmsko-glasbena zgodovina večkrat zamolči: da so glasbo za filme nekoč ustvarjali skladatelji, ki so poznali glasbeno-kompozicijsko stroko, danes pa se, prav zaradi pogoste nekakovosti slovenskega filma, z glasbo pri filmu večkrat ukvarjajo ljubitelji preprostih glasbenih invencij in učinkov. $Z$ drugimi besedami - glasbeno slabo izobraženi posamezniki, s pedigrejem zabavnega, populističnega, všečnega in neproblematičnega žargona. V tej luči bomo nekatere partiture premislili tudi nekoliko pobližje, saj je prav v tem close up poslušanju skrito Adamičevo globlje premišljevanje o sami naravi glasbe, filma in, ne nazadnje, poslušalca.

Ključne besede: Bojan Adamič, jugoslovanski film, filmografija, zgodovina filma, analiza

\section{Razvoj slovenske filmske glasbe in Bojan Adamič}

Filmska glasba Bojana Adamiča zaseda v slovenski filmski zgodovini zagotovo pomembno mesto. Njena vsestranskost in posebnost sta se dokazovali in potrjevali skozi več kot pol stoletja dolgo zgodovino slovenskega in jugoslovanskega filma, mu dajali poseben pečat in ga usmerjali v tedaj najvidnejše evropske ter svetovne tokove. Njegovo ustvarjanje filmskih partitur posega od zabavnih melodij do resnih študij, s katerimi se Adamič vpisuje med filmske komponiste klasične in sodobne generacije. Raznolikost njegovega glasbeno-filmskega ustvarjanja je po eni strani presenetljiva, saj nakazuje na širino glasbenega ustvarjalca, po drugi strani pa pričakovana, saj je bil tako za- 
nimiva vsestranska osebnost, da je bilo komponiranje filmske glasbe zanj pravzaprav dopolnjevanje vsega ostalega, predvsem pa sklenitev vidnega in nevidnega sveta umetnosti.

Bojan Adamič predstavlja skozi nekaj desetletij svojega delovanja vodilno filmsko-glasbeno osebnost, s svojimi partiturami pa je izpisal tudi zgodovino filmske ustvarjalnosti, predvsem slovenske in (tedaj) jugoslovanske kinematografije, ki je zagotovo doživljala prepoznavnost tudi zaradi svoje glasbene podobe, ki ji jo je dodeljeval mojster.

Bojan Adamič se je rodil skoraj sočasno z najpomembnejšimi premiki v svetu filma in filmske glasbe. Leta 1912 je bila filmska glasba že prepoznana kot enakovreden filmski element in mnogi skladatelji so že postavljali prva kompozicijska in filmsko-glasbena pravila za tisto, kar se bo kasneje razvilo $v$ teorije filmske glasbene kompozicije. Bojan Adamič je stopil v svet komponiranja filmske glasbe leta 1946, čeprav se je s filmsko glasbo srečal že med vojnama - kot izvrsten pianist je namreč intenzivno spremljal in aranžiral mnoge druge partiture iz zgodovine filmske umetnosti. In čeprav razpet med fotografijo ter zabavno in popularno glasbo, je ostal zvest prav svojim filmskim partituram do smrti. Težko bi rekli, kateri glasbeni opus je v njegovem življenju najpomembnejši, zagotovo pa se lahko strinjamo, da je opus njegovih filmskih partitur pisal tako zgodovino slovenskega kakor tudi jugoslovanskega filma.

Njegov najbolj prodoren čas skladateljevanja in ustvarjalnosti se je pričel po drugi svetovni vojni. Tedaj je bil že izkušen glasbenik, izredno pomemben za razvoj slovenske zabavne glasbene scene, tedaj priljubljenega jazza in big-band zvoka, $v$ nadaljevanju pa popevke in šansona: le kdo ne pozna njegovih vedno zelenih napevov, kot so Čao Ljubljana, Ko boš prišla na Bled, Prelepa si bela Ljubljana, Prodajalka cvetja, Starec in morje, Školjka, Stari Mercedes, Ti si mi vse, pa šansone, med katerimi še pomnimo naslove Balada o človeku, Človek na sredi, Romanca o delu ... Zagotovo velja omeniti še njegovo scensko glasbo za gledališče: Bela krizantema (I. Cankar), Krčmarica Mirandolina (C. Goldoni), pa Šola za žene (J. B. Molière) ter kar nekaj glasbe za drame Shakespeara - Romeo in Julija, Macbeth, Hamlet, Sen kresne noči in Richard III. Napisal je tudi tri balete (Moje ljubljeno mesto, Bela Ljubljana in Plesalka) ter en muzikal (Sneguljčica). Slovenski zbori poznajo njegovo ime po skladbah $\checkmark$ Gorjah zvoni, Domov bom šel, znanih pa je tudi precej partizanskih pesmi za zbor in orkester. Ob vsem tem pa ne smemo spregledati njegove glasbe za radijske igre, med katerimi so najbolj legendarne Žogica Marogica, Brkonja Čeljustnik in Zvezdica zaspanka - za svoj revijski oz. plesni orkester jih je napisal več kot 200! Bolj koncertno usmerjena publika pa se ga zagotovo spomni po komornih delih (Mesečina na Travni gori za violino in klavir, Preludij za kitaro, Suita za harmoniko ...) in skladbah za simfonični orkester (dva klavirska koncerta, Rapsodija, 
Suita za klarinet in godala, Sedem preludijev za klavir in orkester ....). Skratka - velik opus.

S filmsko glasbo se je Adamič zapisal tako v slovensko kakor tudi jugoslovansko filmsko zgodovino, pisal pa je tudi glasbo za filmske studie v ZDA, Švici, na Madžarskem, v Nemčiji, nekdanji Sovjetski zvezi, Franciji, Veliki Britaniji in celo Braziliji ter na Norveškem. Njegov opus obsega preko 200 partitur za celovečerne in kratkometražne filme, ob tem pa še za televizijske Obzornike, TV drame in filmske serije. Kot njegova prva filmska glasba je zabeležena partitura za kratkometražni film Maščujmo in kaznujmo (1946, režija Dušan Povh), ${ }^{2}$ film o zločinih belogardističnega generala Leona Rupnika, njegova prva partitura za celovečerni film Svi na more (režija Sava Popović, v glavnih vlogah Milan Ajvaž, Milena Dapčević in Milan Puzić) pa je nastala leta 1952 (Nedić 2011 in 2012). ${ }^{3}$

\section{$1950-1960$}

Bojan Adamič je petdeseta leta pričel s filmsko glasbo kratkih dokumentarnih filmov, med katerimi so Sportovi na vodi (1951, režija Ljubiša Popović), ${ }^{4}$ Na obalama Kvarnera (1952, režija Marijan Vajda), ${ }^{5}$ Slike iz Slovenije (1952, režija Marijan Vajda), ${ }^{6}$ Jedan naš dan (1952, režija Miodrag Nikolić), ${ }^{7}$ temu pa so sledili že omenjeni celovečerec Svi na more, pa Biser Jadrana - Dubrovnik (1953, režija Marijan Vajda) ${ }^{8}$ ter Jara gospoda (1953, režija Bojan Stupica, v glavnih vlogah Vladimir Skrbinšek in Elvira Kralj) in končno film vseh slovenskih filmov - Vesna (1953, režija František Čap, v glavnih vlogah Metka Gabrijelčič, Franek Trefalt, Jure Furlan, Janez Čuk in Elvira Kralj). Iz tega obdobja velja omeniti še filme Trenutki odločitve (1955, režija František Čap, v glavnih vlogah Stane Sever, Julka Starič in Stane Potokar), Otok galebov (1956, režija Ernest Adamič), ${ }^{9}$ U mreži (1956, režija Bojan Stupica, v glavnih vlogah Mira Stupica, Bert Sotlar, Jurica Dijaković in Vika Podgorska), vojni film

\footnotetext{
${ }^{1}$ Delno povzeto po http://www.bojan-adamic.si/ (dostopno: 12. marec 2018)

${ }^{2} \mathrm{Ni}$ podatkov o igralski zasedbi.

3 vir: Excelova tabela (uredila Lilijana Nedič, maj 2012), na http://www.bojan-adamic.si/ (dostopno 12. marec 2018)

${ }^{4} \mathrm{Ni}$ podatkov o igralski zasedbi.

${ }^{5} \mathrm{Ni}$ podatkov o igralski zasedbi.

${ }^{6} \mathrm{Ni}$ podatkov o igralski zasedbi.

${ }^{7} \mathrm{Ni}$ podatkov o igralski zasedbi.

${ }^{8} \mathrm{Ni}$ podatkov o igralski zasedbi.

${ }^{9}$ Ni podatkov o igralski zasedbi.
} 
Potraga (1956, režija Žorž Skrigin, v glavnih vlogah Ljubiša Lovanović in Vasa Pantelić) ter Veliki i mali (1956, režija Vladimir Pogačić, v glavnih vlogah Jožo Laurenčič, Severin Bijelić in Ljuba Tadić), tu je še drama Krvava košulja (1957, režija Žorž Skrigin, v glavnih vlogah Dušan Bulajić, Marija Crnobori, Ana Nikolić in Mira Nikolić), pretresljivi celovečerec Ne obračaj se, sine (1956, režija Branko Bauer, v glavnih vlogah Bert Sotlar, Lila Anders, Zlatko Lukman in Mladen Hanzlovsky), za oddih je sledil kratek, a učinkovit animirani film Fantastična balada (1957, režija Boštjan Hladnik - film o Miheličevih grafikah), za njim pa še hudomušno kratek Najlepši cvet (1957, režija Saša Dobrila - zgodba čebele, sveta in trota) ter Tuja zemlja (1957, režija Jože Gale, v glavnih vlogah Rade Marković, Ilija Đuvalekovski, Milorad Margetić in Tamara Miletić).

Zagotovo je naslednji veliki domet $v$ tem času film Tri četrtine sonca (1959, režija Jože Babič - v glavnih vlogah Arnold Tovornik, Bert Sotlar in Lojze Potokar), nato partitura za film X-25 javlja (1960, režija František Čap, v glavnih vlogah Dušan Janičević, Tamara Miletić, Angelica Hlebce in Stevo Žigon) ter Ljubav i moda (1960, režija Ljubomir Radičević, film z mlado Bebo Lončar v glavni vlogi, ob njej pa Miodrag Petrović-Čkalja in Mija Aleksić).

$\checkmark$ filmu Vesna gre brez dvoma najprej za glasbeni in filmski diskurz ženske/dekleta, nato njene besede in navidezne ne-prisotnosti, glede tega se lahko dotaknemo še kakšnih ključnih topik filmsko zvočnega koda, predvsem pa je zanimiva Adamičeva partitura, ki sooblikuje sekvenco pisma. Film Vesna brez dvoma spada v tako imenovano slovensko filmsko »klasiko« in ga je potrebno $z$ vsem spoštovanjem tako tudi obravnavati. $\vee$ osnovi je $v$ njem na različne načine nagovorjen slovenski ženski (filmski) lik tedanjega časa - ženska/dekle je namreč bistveno odsotna: manjkata ji podoba in ime, čeprav pride pismo na pravi naslov in pravemu dekletu v roke. Vendar se prav zaradi pisma pripoved tudi usodno obrne. Ta je (kljub današnjim elektronskim različicam) še vedno posebno mesto diskurzivnega nagovarjanja osebe, ki je vedno »na drugi strani zrcala«, kot bi rekla Alica.

Besede, ki jih na papirju izreka Samo (Franek Trefalt), so polne skušnjav in zmešnjav. Filmski suspenz, s katerim se na velikem platnu ukvarjata Čap in z njim Adamič, je evidenten: besede bere Janja (Metka Gabrijelčič), fiktivna Vesna, za katero Samo meni, da je Hiperbola (Olga Bedjanič) - hči mojstra profesorja Slaparja (Stane Sever), ki ga vsi kličejo Kozinus. Za komedijo zmešnjav je sploh značilno, da se ne ve, kdo je kdo. Imamo le pismo, v katerem je ključna prvoosebna izpoved. Hrepenenje, kot ga je predstavljala Julija Prešernu. Toda: Julija je mit in Vesna prav tako - kakor nas opominja Močnik, ki pravi, da je mit pripoved, ki organizira svet. Svoj organizacijski učinek najpogosteje dosega s tem, da pripoveduje o začetkih ali, natančneje, o izvirih (Močnik 2006). To je posebej pomembno, če primerjamo filmsko junakinjo $s$ Prešernovo devo. Če je mit pripoved o organizaciji sveta, potem je se- 
veda filmska pripoved $v$ tem primeru organizacija sveta, $v$ katerem živi in deluje filmska junakinja. Zunaj tega sveta ni mita in zunaj tega mita (pripovedi) seveda njen svet razpade. Zakaj? Junak Samo ne pozna njenega pravega videza ali še bolje rečeno, prepričan je, da je njen videz drugačen, kot je $v$ resnici. Zato so njegove besede pravzaprav hinavske, polne besednih leporečij in trikov. So pripoved o nastanku navidezne ljubezni, virtualne resnice, $v$ katero pa se današnji svet tako ali tako spreminja. Tudi Julijin mit se ne začne kot pripoved, temveč kot formula (Močnik 2006, 48). To poudarjamo zaradi stavka v pismu, ki pravi: In vi niti ne slutite, da odmeva gori koprneča pesem o vaših očeh.

Adamičeva glasba se kot tretji glas pridruži popolni zmešnjavi. »Pesem« spremeni v »skladbo«, igrano na violino (kakor da bi Samo igral ta instrument, čeprav vemo, da ga ne), akuzmatičen glas, ki pa prebira pismo v Vesnini »glavi«, je Samov, čeprav ona (Vesna/Janja) sploh ne ve, kdo je njen oboževalec. Napaka? Kje pa. Pri filmu je pomembna identifikacija. Toda ne junaka/junakinje, temveč gledalca, ki je tukaj ujet v past zvoka-glasbe-besede. Samov glas je past, ki se je razprla v hipu, ko je Janja odprla pismo, zapre pa se takoj s preskokom v realnost, ko Janjo pokliče oče po "pravem« imenu in se njen »sanjski« svet, svet glasovnega privida, popolnoma podre.Z njim se podre glasba in izgine glas oboževalca. Vesna postane mit, ki ga mora izpeljati filmska Janja in privoliti v zmenek.

Pomembni so učinki:

1. Diskurz filmsko-glasbenega komentarja, filmske kritike ali interpretacije se z njo vzpostavi $v$ diskurz vednosti - lahko bi nastala filmska veda o pomembnem obratu glasu v Adamičevo glasbo.

2. Filmski Samo je postal subjekt, filmu pa je prav Adamič pripisal nekaj naddoločenega, torej glas/zvok in glasbo violine, s katerima subjektivizira virtualen odnos, ki ga poimenuje "pomlad", torej »Vesnaw. Ta obrat je pomemben $v$ diskurzu identitet.

3. Ta matrica »glasbenega-zvočnega« pisma je dejansko matrica naddoločitve (funkcije) dekleta, ki ga ni (Vesne), in Janjin fiktivni prevzem dvojne vloge - skozi simbolno razsežnost pride do subjektivizacije dekleta, ki se ujame v glasovno-glasbeno-violinsko past. Pri tem pa vsekakor Janja (kot Julija) izgine.

Adamičeva glasba in zvok sta $v$ dialektični poziciji do filmske podobe, a vendar delujeta homogeno. Gre za transsubstancialni moment, $v$ katerem se gledalec spusti po toboganu verjetnega, se prepozna $v$ junakih našega časa in zajaha poštenega konja. Toda čista libidinalna ekonomija tega odnosa gledalec - junak ali gledalka - junakinja se zvrne na vidik enega subjekta, ki se ( $v$ filmu) vedno sreča z nekakšnim likom ultimativne groze, nepoštenosti ali prevare, s katero mora opraviti in življenje (kako romantično!) postaviti na kocko. Glasbena poanta je skoraj vedno $v$ tem zvočnem utelešenju junaka (a redko junakinje), 
saj (p)ostane nevidna, kot so sanje o sreči, poštenju in miru. Glasba in zvok vselej postaneta kontra subjekta, nekakšen nevidni drugi subjekt pripovedi, ki lahko seže ultimativno tudi prek smrti. Filmska Vesna/ Janja se ne more odreči svoji dvojnosti, za boljše razumevanje pa bi si bilo na tem mestu treba pogledati in spregovoriti tudi o filmu Ne čakaj na maj (1957, režija prav tako František Čap, glasba pa Borut Lesjak).

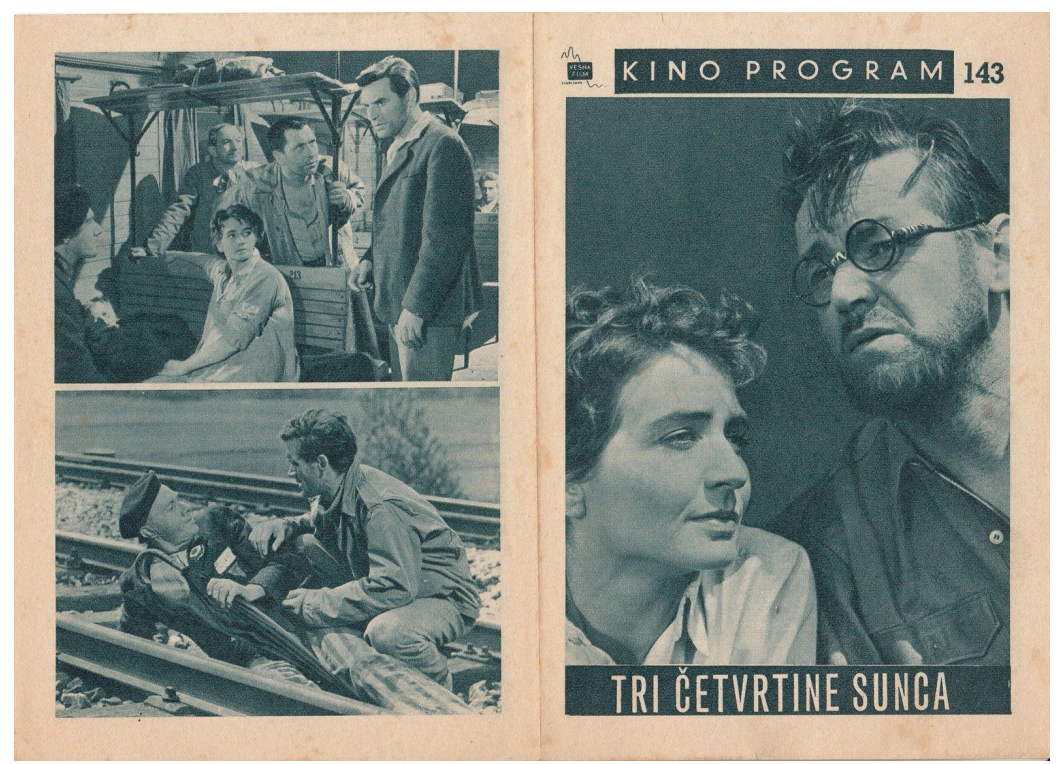

Slika 1 - Letak za film Tri četrtine sonca (1959)

\section{3/4 (Tri četrtine) sonca (1959, režija Jože Babič) ali zgodba o zgodbah}

Vsebina filma pripoveduje o tem, kako se ob koncu druge svetovne vojne »skupina taboriščnikov različnih nacionalnosti znajde na Češkem, kjer jih naključje primora k skupnemu življenju v železniškem vagonu. Porajajo se prijateljstva in sovraštva, priča smo požrtvovalnosti in odrekanju, sumljivemu taboriščniku, ki je $v$ resnici predstavnik nemške vojske. Eden izmed "prebivalcev« vagona se domov odpravi peš, drugi hrepenijo po prihodu vlaka, ki jih bo odpeljal naprej, ki jih bo odpeljal domov. Jim bo uspelo? «10

Filmska partitura, ki jo Adamič ponudi v tem filmu, je sestavljena skoraj epizodno. Lahko bi celo rekli, da se v bistvu ukvarja s filmskimi liki in njihovimi notranjimi svetovi in strahovi, veliko manj pa s tisto »klasično« filmsko-glasbeno pripovedjo, ki je bila tedaj najbolj razširjena. Partitura vsebuje elemente večjih in daljših melodičnih za-

10 Citirano po http://www.film-center.si/index.php?module=fdb \&op=film \&filmID=1847 (dostopno: 13. april 2018). 
mahov, vsekakor pa tudi nekaj intimnega premišljevanja in situacijske problematike. Sama partitura je s svojimi oseminsedemdesetimi stranmi pravzaprav kratka, vendar vsebuje vse, kar pravzaprav dobra filmska partitura potrebuje - sestavljenost iz odlomkov, delov, kosov, ki se filmu prilegajo. Kakor bi dober krojač skrojil obleko, ki ustreza brez velikih popravkov. Adamič $v$ njej večkrat zaniha med čistim simfoničnim zvokom, ki pa se zna v nekaterih odlomkih nasloniti celo na jazz zvoke, zvoke simfonično-plesnega orkestra. Vendar ostane nenehno v obvladanih, »serioznih« tonih in, ne nazadnje, izpoveduje idejo, ki jo nosi s seboj tudi film: vzajemnost filmskega in glasbenega jezika, prijateljstvo, hrepenenje in upanje. Adamič se, lahko bi rekli, ukvarja s filmskim pomenom. Toda pomen je vedno trdno jedro simptoma, je torej ujeta enigma, je izjavljanje brez izjave, če pa je filmska podoba enako kot Drugi hkrati tudi sama presežek, nas to napeljuje do nedvomnega sklepa, da je jedro filmskega subjekta tako rekoč le formalno in da je subjekt $v$ odnosu do podobe temeljni pogoj za fantazmo, edina možna pot razveza, pa je njen radikalni razcep izražen kot nevroza, kot osamljenost sredi množice. Film z naslovom $3 / 4$ (Tri četrtine) sonca je prav tako pripoved o tem. Bojan Adamič je $v$ tem filmu tudi liričen, vendar na svoj način. Vedno se ukvarja s prisotnostjo glasbe $v$ trenutkih, ko je potrebno komentirati emocionalno plat neke sekvence, ko se pojavijo dvom, pričakovanje, želje, upi in obupi - in ne nazadnje hrepenenje. $Z$ orkestracijo pokaže na komornost likov, $v$ instrumentalnih dialogih na zgodbe filmskega prijateljevanja, sodelovanja in sovražnosti, $v$ simfoničnih zvokih pa razpre hrepenenje $z$ odprtimi glasbenimi frazami, kakor bi se želje po boljšem življenju prelile iz filmskih likov $v$ ušesa poslušalcev.

\section{Ljubav i moda (1960, režija Ljubomir Radičević) ali zgodba o drugačnosti}

Sama zgodba filma gre na hitro takole: »skupina študentov organizira modne revije za podjetje Jugošik, da bi zaslužili denar za organizacijo letalske revije. Pri tem se poslužujejo tudi majhnih prevar. Cilj je plemenit, revija uspe, škode ni, niti za študentko Sonjo niti za mladega modnega oblikovalca Bora, ki na koncu rešita svoja nesoglasja.V fontani. «11

Dvojnost filmske partiture tega simpatičnega jugoslovanskega filma je pravzaprav ujeta že v naslovu - ljubezen in moda. Na prvi pogled lahko razumemo, da gre za par, vendar skozi film razberemo, da sta obe zadevi lahko tudi v kontra-poziciji in bi lahko mednju zapisali celo »ali«, čeprav bi bil smiselno nastavljen tudi »kot«: torej ljubezen kot moda. Adamič se v tem filmu ukvarja z bistveno bolj zabavnimi ritmi,

${ }^{11}$ Citirano po http://www.film-center.si/index.php?module=fdb\&op=film\&filmID=1860 (dostopno: 14. april 2018). 
med katerimi zasledimo swing in be-bop, se pravi točno s tem, kar pač ponujata ideja filma in svet mode; ljubezen pa se (mu) v glasbi zazdi kot spremljevalka procesa, ki je tako ali tako nekaj »vzporednega«.

Film, pa tudi druge oblike umetnosti, usmerja posameznika in posameznico ter jima razkazuje njuno vlogo v družbi in njuno socialno vrednost - ter ne nazadnje njuno pozicijo. Posameznik in posameznica na temelju svojih potreb prevzameta iz filma vedno tisto, kar ocenita, da je pomembno zanju, za njuno vlogo v družbi in življenju. Psihološko gledano posameznik in posameznica $\vee$ film nenehno projicirata sebe in tako prevzemata različne fiktivne statuse in vloge. Po mnenju tedanjega časa ( $v$ mislih imamo čas povojnega »ozaveščanja« z modernimi idejami, torej čas in prostor nastanka prav tega filma) film ni le del oblike zabave, temveč del razumevanja in prepoznavanja sveta ter videnja svoje lastne vloge $v$ njem. Vsekakor bi veljalo posebej govoriti o propagandnem in izobraževalnem filmu, vendar to ni trenutni namen. Številni sociologi so bili od nekdaj okupirani s težavo, kako film učinkuje na otroke in mladoletnike, na njihovo delikventnost, emocije in druga socialna vprašanja vzgoje in medosebnih odnosov ter rasnih nestrpnosti, ideologij in spolnih navad (Adolf Adler, Silvia Payne, Louis Leon Thurstone, Siegfried Kracauer). Posebno sociološko vprašanje filma je tudi ljubezen.

Veliko stvari povezujemo z ljubeznijo: do človeka, do narave, do življenja ... Tudi filmska glasba je pripomogla $\mathrm{k}$ tem idejam precej nesmrtnih zapletov, napevov, zvokov, intimnih harmonij in drugih sozvočij. Skoraj ni filma, v katerem ne bi srečali takšne ali drugačne oblike ljubezni. Ljubezen ima tisoč obrazov in tisoč oblik, neskončno načinov izpovedi in neskončno možnosti, da se izrazi. Ljubezen je kot zajčje poti, le-te pa so pomladi dobro vidne, toda zamotane (Ksenofan 1963 , 221), bi lahko rekli. Tako zamotane, da na koncu zasledovanja več ne vemo, ali zasledujemo zajca ali že kar sebe. Kakor zapiše Rotar, ni drugega diskurza, razen diskurza manka. Prav zato ima relacija med zunaj in notri v humanističnem diskurzu nenavaden pomen (Rotar 1981, 40). Seveda hočemo razumeti filmsko glasbo in filmsko podobo kot nekaj, kar se dogodi navidezno zunaj subjekta, torej v njegovem opazovalnem in slušnem polju, kakor hočemo razumeti film (le) v pomenu filmske podobe. Tisto notri pa je kakor nevidno, nevidljivo, skrito očem, vendar slišno, torej najbolj sublimno. In sled, ki jo pušča zunanji svet v notranjem in jo notranji manifestira v zunanjem, je temeljna magija filmske umetnosti. Je njegov habitus, njegov ego. Kakor ljubezen, ki spaja. A težava pri ljubezni je vedno $v$ tem, da jo je treba izgovoriti. Treba jo je pripovedovati - tako ali drugače.

$\mathrm{K}$ temu prištevamo tudi glasbo Bojana Adamiča - točno iz tega filma. Čeprav je mogoče največji filmsko-glasbeni hit postala pesem Devojko mala (glasba Darko Kraljić, besedilo Boža Timotijević), pa je vendar prav nekaj več kot osemdeset strani dolga Adamičeva partitura 
znak, da je kot skladatelj vnašal zabavne zvoke $v$ simfonično-plesni orkester in tako zabrisal mejo med tem, kaj je pravzaprav film: umetnost $v$ svetu zabave in/ali zabava $v$ svetu umetnosti. Že otvoritvena pesem Jedna mala dama nas nagovori v ideji šlagerjev, kjer se Adamič najde potem med svojimi napevi: Hej, stani dečko, pa Šta je to, ko je to, v nadaljevanju pa še Šiparica in Tajna. Vsekakor pa moramo priznati, da je naslovno pesem Ljubav i moda naredil Darko Kraljić in z njo požel pravzaprav uspeh celotnega filma.

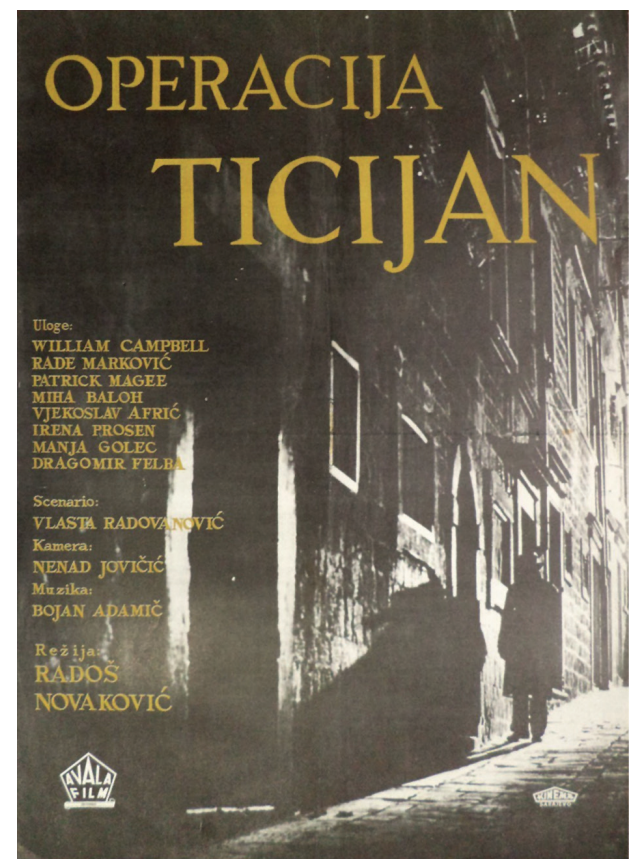

Slika 2 - Plakat za film Operacija Ticijan (1963)

1961-1970

To obdobje je Adamič pričel nekoliko lirično. Prvi takšen film je bil Košček modrega neba (1961, režija Svetomir Janić, v glavnih vlogah Rahela Ferari, Pavle Vujišić, Petar Prličko, Olivera Marković in Boris Kralj) in zdi se, kakor bi se pripravljal na veliki zamah, ki je nastal še istega leta s filmom Ples $v$ dežju (1961, režija Boštjan Hladnik, v glavnih vlogah Duša Počkaj in Miha Baloh). Sledijo filmske partiture za celovečerce $P e$ ščeni grad (1962, režija Boštjan Hladnik, v glavnih vlogah Janez Albreht, Milena Dravić, Ali Raner, Špela Rozin in Ljubiša Samardžić), Operacija Ticijan (1963, režija Radoš Novaković, v glavnih vlogah William Campbell, Rade Marković, Patrick Magee, Miha Baloh in Irena Prosen), izredno art-provokativni Erotikon (1963, režija Boštjan Hladnik, v glavnih vlogah Ingrid van Bergen, Michael Cramer in Gunnar Möller), v odgovor 
pa Samorastniki (1963, režija Igor Pretnar, v glavnih vlogah Majda Potokar, Vida Juvan, Rudi Kosmač, Lojze Rozman in Stane Sever). Tem sledi družbena drama Lažnivka (1965, režija Igor Pretnar, v glavnih vlogah Dušan Antonijević, Danilo Benedetič, Rusa Bojc in Angelca Hlebce) in ponovno vojna drama Sretni umiru dvaput (1966, režija Gojko Šipovac, v glavnih vlogah Mija Aleksić, Nikola Angelovski, Dragomir Felba in Miloš Kandić). Z mladinsko tematiko tedanjega časa se Adamič sreča dve leti kasneje, ko je ustvaril simpatično partituro za Kekčeve ukane (1968, režija Jože Gale, v glavnih vlogah Polde Bibič, Boris Ivanovski, Zlatko Krasnič in Jasna Krofak), leto za tem pa še glasbo za film Most (1969, režija Hajrudin Krvavac, v glavnih vlogah Bata Živojinović, Slobodan Perović, Boris Dvornik in Relja Bašić). ${ }^{12}$

\section{Ples v dežju (1961, režija Boštjan Hladnik) ali zgodba o hrepenenju}

Film Ples v dežju (glasba Bojan Adamič) se ukvarja pravzaprav $z$ več »mračnimi« elementi, ki pa so bili pravi hit tedanjega časa. Zgodba pravi, da »slikar Peter pooseblja moško hrepenenje po sreči rad bi srečal idealno žensko, popolno življenjsko sopotnico. Gledališka igralka Maruša, s katero ima Peter stalno razmerje že sedem let, bi rada živela z njim in si z njim tudi vse delila. Toda Peter se je Maruše že rahlo naveličal. Ponoči Maruša začuti, da jo je Peter zapustil. Tudi ona se odloči, da je konec njunega razmerja morda najboljša rešitev. Toda na koncu oba ugotovita, da sta izgubila nekaj zelo pomembnega. Medtem dva mlada zaljubljenca plešeta v dežju, na ulici. Mogoče bosta dosegla srečo, ki sta jo Peter in Maruša zaman iskala. ${ }^{13}$

V času nastajanja tega filma je ameriški prevladi na trgu konkurirala le nemška filmska industrija. Njen najbolj prepoznaven prispevek so bili temni, celo halucinatorni svetovi nemškega ekspresionizma, ki so povečali moč antirealizma, na platno pa postavili notranje konflikte, duhovna stanja posameznika in močno vplivali na poznejše grozljivke, psihodrame in kriminalke. Skratka - na temen žanr. Prav iz tega vzdušja je pozneje črpal film noir. Vsekakor je treba (in morda prav pri filmu) vedno sočasno misliti in opazovati tehnologijo in njene družbene učinke, nato tehnologijo in njeno vsebino, potem tehnologijo in njenega uporabnika ter končno tehnologijo in vse njene znane in neznane omejitve. Tako pridemo do vpogleda funkcije, ki jo ima (in jo je imel) film v vsakem trenutku in na vsakem mestu.

Ko gledamo in poslušamo filmski odlomek iz filma Ples $v$ dežju, $v$ katerem glavni junak nenehno teče mimo krst in hiti proti oknu, za

12 viri: http://www.film-center.si/index.php?module=fdb\&op=people \&peopleID=7 in http://www.imdb.com/ (dostopno: 15. maj 2018).

13 Citirano po http://www.film-center.si/index.php?module=fdb \&op=film \& filmID=1872 (dostopno: 11. maj 2018). 
katerim je vidna silhueta ženske (filmske femme fatale), ne moremo mimo tega, kar pravi Derrida, ko bere Kafko. Pravi namreč, da identiteta teksta ni dosežena znotraj zagotovljene zrcalne refleksije, temveč v neberljivosti teksta, sploh če pod tem razumemo nemožnost, da bi prišli do njegovega pravega pomena (Derrida 1992, 211). Tako se vse začne in konča $v$ nekakšnem suspenzu glasbene vednosti, bodisi o tem, kar je pričakovano, bodisi o/v tem, kar je zamolčano, prikrito, umaknjeno prvemu pogledu in sluhu. Ne pa tudi mislim. Za komunikacijo zvokglasba-gledalec ni nujno, da je vedno in samo zvočna. Lahko je postavljena kot suspenzija $v$ film, torej nekakšna razredčina, ki jo moramo znati precediti. Če je bil torej Hitchcock mojster slikovnega suspenza, tistega, ki je vezan na filmsko podobo in naracijo, potem je tedaj stal ob njem drug mojster zvočnega suspenza: Bernard Herrmann. Kakor v tem času pri Hladniku - Adamič.

Morda je bila to največja Adamičeva glasbena vloga v slovenskem filmu. Kontinuiteta zvočnih elementov te sekvence se namreč preoblikuje $v$ svojevrstno zvočno pripoved, za katero pa mora biti poslušalec vsaj dovolj občutljiv in podkovan. A vendar gre v povedanem tudi za poseben paradoks: ali ne bi mogli gledati in poslušati filma tudi brez vse te teoretske navlake? Bi nam bil film zato nesmiselno prikazovanje sličic, blebetanje brez notranje povezave in misli? Kajti: brez slehernega znanja ali izrecnega napotka lahko stopimo do kakšne najpomembnejših stvaritev (kipa, slike), pa bomo kljub temu postali pozorni na nekatere posebnosti (Morelli 1891, 288). Torej gre za moč kreatorja umetnine, tistega, ki nagovarja z nebesednimi elementi, vendar moramo pri tem upoštevati vsaj minimalen skupen kulturni kod med avtorjem in opazovalcem. Toda razumevanje pomena suspenza filmske glasbe in zvoka bi morali absolutno razumeti tudi kot izjavljanje (izrekanje) o nečem, kar je tako rekoč neizrekljivo. Ker vznikne kot nekakšna notranja transformacija misli in idej, kot opozicija sliki, zgodbi, podobi, vsebini, kot nekakšna ontogeneza, kot izjava zunaj vsakršne časovne ali druge modalne določitve (Benveniste 1966,159-160). Lahko bi tudi rekli, da gre za nekakšen premik v prostor, kjer je prostorskost izrazito navidezna, suspendiran zvok, glas, glasba pa fantazma, ki pomaga pri subjektovi želji, da preživeti filmski dogodek. Ali pa ga ne. Pravzaprav je za razumevanje celotne ideje partiture dovolj, da poslušamo Blues hrepenenja, samo enajst strani dolgo partituro, ki jo je Adamič izluščil iz filma in je bila večkrat predstavljena kot samostojna kompozicija. Morda res ne gre za blues v njegovem osnovnem pomenu, vendar je njegova otožnost dejansko tista, ki Adamiča vodi preko skoraj štiriminutne kompozicije. Jasna, valujoča melodija se kakor iluzija vrti vedno okoli iste točke, kakor bi hotela povzročati hipnotičnost plesnega trenutka Maruše (Duša Počkaj), se konča tam, kjer je pričela - v vedno vrtečem se krogu želja, upanja in hrepenenja. 


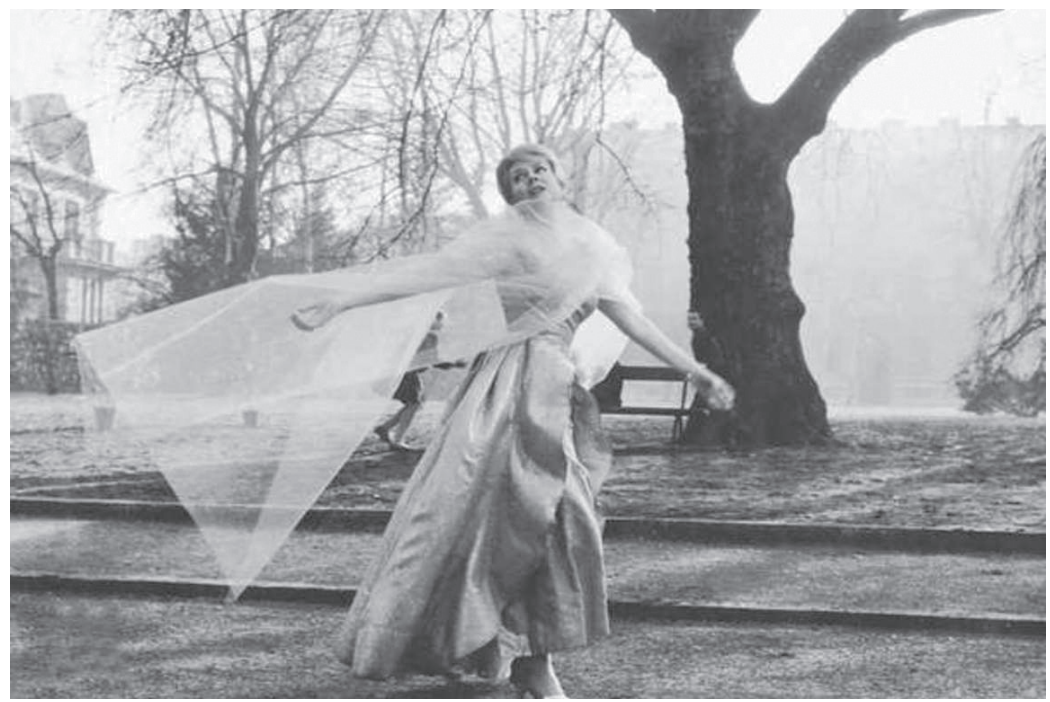

Slika 3 - Prizor iz filma Ples v dežju (1961)

Film Ples $v$ dežju je brez dvoma velik film, poročevalec časa svojega nastanka in hkrati njegov pomnik. Adamičeva partitura pa drzna, sodobna in domišljena. Podpira in razpira Hladnikovo idejo filmskega suspenza. Vendar recimo, da velja nekakšen splošni izrek, da je bil režiser Alfred Hitchcock mojster suspenza. Mnogi, ki to poudarjajo in suvereno ponujajo kot teorijo filma, si pod idejo suspenz ne predstavljajo veliko. Če izhajamo iz stare latinščine, potem je izvorna beseda seveda suspensus, kar pa pomeni, da nekaj visi ali da je še neodločeno. Torej, da gre za nekakšen odlog, premaknitev - morda je zanimiva tudi uporaba besede suspenzija, ki nastane, kadar je neka snov $v$ obliki najmanjših možnih delcev enakomerno porazdeljena $v$ redkejši snovi. In še nekaj je suspenz: filmska pripovedna tehnika, s katero se vodi filmsko pripoved $v$ dveh smereh. Gledalec tako enako verjame, da sta možni opcija A in opcija B, odvisno od kombinacije. Ali recimo, da poznamo možnost $A$, vsi filmski indici pa nas hočejo prepričati, da je edina možnost B. Ta dvojnost, dvotirnost, »obojemožnost« in hkrati umanjkanje ene »prave« možnosti, je filmski suspenz. Premaknitev, celo zatajitev ali suspenzija, v kateri je veliko manjših delcev filmskega zvoka in glasbe porazdeljenih po celotnem filmu.

Tako pozna tudi filmski zvok Bojana Adamiča v tem delu svoj suspenz, vendar na drug način. Zvoku moramo najprej natančno prisluhniti in ga nato interpretirati. Če gre za splošno znane ali veljavne zvočne pojave, s tem načelno nihče nima težav. Te nastanejo, kadar so prisotni zvoki in/ali glasba, ki je mnogi ne znajo interpretirati. Suspenz je lahko naravnan na več načinov: kot začasni, kadar filmska pripoved prikrije kakšen pomemben podatek, kot stalni, kadar ima gledalec ne- 
nehno občutek, da je nekaj prezrl, kot difuzni, saj ta dopušča različna sklepanja, in kot fokusirani, torej kakor nekakšen spoj dejstev, ki nastane šele $v$ nekem določenem trenutku. Pri vseh oblikah pa gre za moč interpretacije.

\section{Kekčeve ukane (1968, režija Jože Gale) ali zgodba o metafori in junaku}

»Pogumni Kekec se v tem filmu s pomočjo svojih starih prijateljev, Mojce, Briclja in Rožleta, ponovno upre krutemu in zlobnemu divjemu lovcu Bedancu. V tretjem filmu o Kekcu se glavni junak spopada z najhujšimi težavami, saj Bedanec obenem ujame Briclja in Rožleta. Kekec ju reši, ob tem mora izkoristiti vse ukane in prevare, Bedanec pa se na koncu zaradi svoje lakomnosti ujame $v$ lastno past. Kekec s prijatelji usliši njegove prošnje, a Bedanca ne izuči prav nič. Bo mir in spokojnost v gorske kraje lahko spet prinesel spoštovani modrec Vitranc? «14

Pripovedovanje je namreč tisto, kar je ustvarilo človeštvo (Janet 1928, 261), in ni ga junaka, ki bi to lahko zanikal. In to je metafora. V sodobnih Atenah imenujejo javna prevozna sredstva metaphorai. Tam se ljudje srečujejo, se dotikajo drug drugega, si gledajo $v$ oči in so, če to hočejo ali ne, $v$ kontaktu, $v$ razmerju, $v$ odnosu. In ko gredo na delo, $\checkmark$ mesto ali domov, se spet družijo $v$ teh metaforah, prečkajo življenje drugih ljudi in se morda celo (za)ljubijo. Tako imajo strukture prevoza funkcijo prostorskih sintaks - seveda s celotno paleto kodov, urejenih načinov ravnanja in nadzorovanja. A vendar so. So metafore, so intimne zgodbe srečevanj, potovanj, so ljudje. Vsaka pripoved je pripoved o potovanju - je torej tudi prostorska in časovna praksa.

Adamičeva partitura ni »otroška« ali pa »kekčevska« ali pa »mladinska«. Ne, prav s to glasbo se Adamič postavi na mesto filmskega sooblikovalca, kjer je njegova govorica zvok. Ujame idejo zgodbe in jo spremeni v glasbeno metaforo - v spretnega Kekca, nesrečnega Briclja, boječega Rožleta, divjega Bedanca ... Adamič ne pozabi, da je glasba umetnost časa in da se glasbena pripoved zgodi v filmskem prostoru prav tako realno, kot se filmski junaki premikajo po časovni premici filmske pripovedi atenskega javnega prevoza, prek in skozi metafore prostorov in krajev. Filmska glasba se jim pridruži na tem potovanju in, kaj je lepšega, odkriva najrazličnejše oblike ljubezni. Projicira jih v temo kinodvorane in nagovarja občinstvo. A ker prostor ni kraj, je treba razumeti to razliko, ki je morda bolj ontološke kot geografske narave, razumeti jo moramo kot poudarek, ki nam ga ponuja film. Za obrat od dejanske filmske glasbe, nekako stran od njene pripovedi, ki je onkraj vidnega sveta, onkraj čiste filmske podobe - se moramo ozreti v film kot $v$ nekaj, kar nam ponuja lahko le umetnost. To je imaginarij. Je prostor

${ }^{14}$ Citirano po http://www.film-center.si/index.php?module=fdb\&op=film\&filmID=1982 (22. april 2018). 
in ne kraj, v katerem se dejansko odigravajo naše želje, je prostor naše osebne ontogeneze, prerojenja, je erotiziran prostor samote, poln ljubezenskega hrepenenja in neskončnih točk, ločenih kot prazni prostori, ki jih polnimo z osebnimi pogledi in izkušnjami (Merleau-Ponty 2006, 293-310).

K vsemu prej povedanemu: mojster Adamič se je prav "popevkarsko« posvetil naslovni pesmi, torej Kekčevi pesmi (na besedilo Frana Milčinskega), a se melodija »dobra volja je najbolja« iskrivo poigrava tudi v drugih filmskih delih, do največjega izraza pa pride seveda prav tedaj, ko jo poje Kekec. Partitura začetka filma predstavlja instrumentalni uvod vanjo, kakor bi šlo za uverturo v gledališkem smislu. Sicer se ta veselost glasbe takoj preplete s streli iz puške (Bedanec je na lovu), kar pa še toliko bolj poudari Adamičevo ne-otroško pojmovanje filmske glasbe tega Kekca. Odlično orkestrirana in izpeljana je tudi partitura kapljanja (Vitranc $v$ jami) in flavtni solo, ki je prav simpatično podoben slavnemu Favnovemu popoldnevu Clauda Debussyja. Temni toni, namenjeni Bedancu, so skoraj dramatično pretirani, vendar se prav $\mathrm{v}$ tem skriva Adamičevo glasbeno oblikovanje filma $\vee$ svetlo-temni tehniki (npr.v prizoru Bedanca in veveričke). Tako dobi tudi škrat Brincelj svoje glasbene motive, drobne in pozitivne melodične teme, $v$ katerih najdemo Adamičev pozitivizem in veselje do dobre in lepe glasbe. Celotna partitura pa je vsekakor hvalnica naravi in vprašanju sožitja s človekom. Ker pa je le-tega v pravem pomenu sposoben le Kekec, je tako večkrat osrednji motiv njegova pesem, njegova metafora pravega življenja, ki se lahko izrazi v soigri Adamičeve partiture in filmske podobe.

\section{1-1980}

Bojan Adamič pričenja to desetletje s partituro za skoraj kultni film Maškarada (1971, režija Boštjan Hladnik, v glavni vlogah pa Črt Kanoni, Bojan Šetina, Franjo Kumer, Bojan Tratnik in Miha Baloh), nadaljuje pa z glasbo za resnično legendarno dramo Valter brani Sarajevo (1972, režija Hajrudin Krvavac, v glavnih vlogah Bata Živojinović, Rade Marković in vsekakor Ljubiša Samardžić). Sledi mladinski film z naslovom Vuk samotnjak/Nolk samotar (1972, režija Obrad Gluščević, v glavni vlogi tedaj izredno mlad Slavko Štimac), v katerem se Adamičeva glasba pojavlja kot spretna interpretka odnosa med dečkom in volkom - prav kot obrnjena glasbena zgodba Peter in volk, ki jo je leta 1936 napisal Sergej Prokofjev. Sledi popularna filmska partitura za nadaljevanko Kapelski kresovi (1974-1976), potem in vmes pa Dekliški most (1976, režija Miomir Stamenković, v glavnih vlogah Miroljub Lešo, Dragan Nikolić in Marko Nikolić) in skoraj večno citirani Idealist (1976, režija Igor Pretnar - v glavnih vlogah pa vidimo tedaj sama velika imena slovenskega velikega platna: Radko Polič, Milena Zupančič, Dare Ulaga, Stevo Žigon, Arnold Tovornik, Bert Sotlar, Janez Albreht in Marjeta Gregorac), za ko- 
nec tega obdobja pa kar trpka vojna drama Nasvidenje $v$ naslednji vojni (1980, režija Živojin Pavlović, v glavnih vlogah Janez Bermež, Željko Hrs, Tone Kuntner in Tanja Poberžnik). ${ }^{15}$

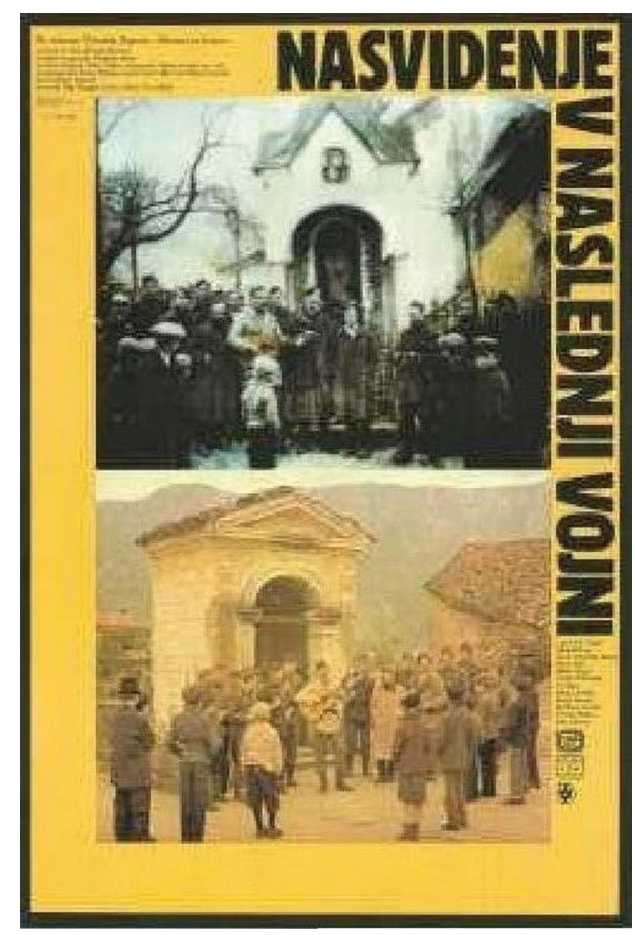

Slika 4 - Plakat za film Nasvidenje v naslednji vojni (1980)

\section{Maškarada (1971, režija Boštjan Hladnik) ali zgodba o različnostih}

Filmska zgodba filma Maškarada pravi, da je »Dina v zakonu z direktorjem Gantarjem zadovoljna, a jo srce in telo vlečeta k mlademu in postavnemu Luki. S pretvezo, da bo mladenič inštruiral njenega sina, omogoči pogostejša srečanja, ki pa jih Gantar zasluti. Na praznovanju sinovega rojstnega dneva, kjer je tudi Luka z deklico Petro, od žene izsili priznanje. Gantar v besu posili Dino, Luka pa ne stoji križem rok, ampak fizično obračuna z Gantarjem, zatem pa z dekletom odpotuje. Po njegovi vrnitvi se dogodki zapletejo, klobčič starševske, prijateljske in erotične ljubezni postaja vedno bolj zapleten. Bo Luki uspelo krmariti med Dino in Petro? Gre za kultni film slovenske hipijevske generacije, ki je na integralno, necenzurirano verzijo z najdrznejšimi erotičnimi prizori čakal več kot deset let.«16

\footnotetext{
15 vir: http://www.film-center.si/index.php (10. marec 2018).

16 Citirano po http://www.film-center.si/index.php?module=fdb\&op=film\&filmID=2007 (11. marec 2018).
} 
Adamič se s svojo partituro postavi na stran vprašanja družbene vloge glasbe - tudi skozi filmski pogled. Družbeni razkoli, ljubezensko-erotični elementi niso neizrekljivi v glasbenem jeziku, zato se jim skladatelj približa z idejo problematiziranja. V Hladnikovih drznih prizorih se $v$ glasbi ne odzove emocionalnost, ki bi naj (ali bi lahko) gledalca »pasivizirala« - filmska partitura ga postavi v nasproten položaj: aktivira ga. Glasba ni del filmskega dogodka, temveč njegova zadržana komentatorka, mestoma celo izzove ekshibicionistično oko kamere, da se poigra s tišino kot z enakovrednim glasbenim sredstvom. Prav zaradi tega lahko rečemo, da sta bila Hladnik in Adamič v tem času pomemben tandem za razvoj slovenske filmske zgodovine. Uvodna glasbena sekvenca se naslanja pravzaprav na sam zvok (letala, radarji, tekma ...), vendar postaja kmalu samoiniciativna. Absolutni erotizem košarkaške igre, očesa kamere in pogledov se $v$ slow-motion delu prelije $v$ Adamičevo glasbeno sekvenco, ki podpisuje praktično ves film. Ne toliko $\checkmark$ glasbeni sekvenci, temveč $v$ emotivnem smislu, $v$ glasbenih frazah, s katerimi se skladatelj vpisuje $v$ Hladnikove drzne slike. Koraki, gibi, kretnje, pogledi, dotiki, tema, objemi, poljubi ... vse to so glasbeni loki, ki odsevajo $v$ partituri kot dialoški principi. Materija filmske resnice je namreč vedno tudi družbena materija. Filmski medij ne more obstajati brez nje. Če se njegova pozicija ne realizira v družbenem imaginariju, se sploh ne manifestira. Ne obstaja. Ne more obstajati zunaj teh meja. Njegova materija je zato vedno vezana na konstrukcije in dekonstrukcije različnih družbenih matemov, na njihovo dinamiko in trenutno ideološko in politično temperaturo.

Vsaka filmska resnica deluje $v$ drugačnih trenutkih in pred drugačno družbo ter javnostjo popolnoma drugače. V sebi združuje namreč neko hegemonijo svoje lastne disjunktivne potence, vsebuje povezovalno materijo, ki je v svojem bistvu vedno povezovalna, korelativna, soodnosna. Prav zato je bil Chaplinov boj proti zvoku v filmu tako srdit. Za vsako ceno je hotel ohraniti »razparcelirano« moč materije filma, saj ni hotel ustvarjati umetne resnice, temveč umetnost, ki ne teži k resničnosti, ki je ne podvaja, kopira in ne poustvarja. Film je hotel videti kot družbeni element v funkciji eksistencialne filmske razsežnosti resnice, torej kot nekaj, kar omogoča pojav resnice, vendar ni resničnost sama, omogoča vprašanja o esencialni dimenziji resnice. Družbena funkcija filma pa postaja zato čedalje bolj realna dimenzija resnice, seveda obrnjene, zrcalne, resnice odmeva in odseva.

\section{Idealist (1976, režija Igor Pretnar) ali zgodba o dekadenci}

»V filmski obdelavi klasičnega slovenskega romana sledimo učitelju Martinu Kačurju, kako se spopada s konservativnim okoljem, a je zaradi svojih naprednih idej premeščen v majhno vasico. Vaško okolje je še bolj moreče, vpliv cerkvene in posvetne oblasti pa še večji. Čeprav 
Kačur spozna Tončko in se z njo poroči, postaja zagrenjen in razočaran. Ko se družbeno okolje omili, Kačurja premestijo v prijaznejše okolje, a so se rane časa, ki so jih povzročile vse krivice, zažrle pregloboko. V nasprotju z ženo Kačur ne more razumeti sprememb. Umre mu še sin. Bo zmogel ohraniti svoj elan in voljo ter nadaljeval z izobraževanjem neukih množic? Ga bo prekril sneg in za vedno pokopal njegove ideale? « ${ }^{17}$ In Kačur je seveda idealist.

Vsaka dekadenca se začne z glasbeno dekadenco. To trdimo predvsem zato, ker s filmsko glasbo dekadentni akademiki ne morejo početi prav veliko. Brž ko je ugodje postavljeno kot merilo, zagrešimo tako rekoč svetoskrunstvo. Pravijo, da je merilo pravega v glasbi pravzaprav v njenem učinku ugodja. Toda to je nevzdržno mnenje, pravi Platon (1982, 655 d). Vse to poudarjamo z razlogom. Zavedamo se, da lahko (in morda je prav to pomembno) Adamičevo filmsko glasbo poslušamo tudi ločeno od filmskih podob ter se zagledamo $v$ njeno kompozicijsko strukturo in glasbeno idejo kot analitiki, ki opazujemo zvok z očmi dogodka glasbe. Kot umetnost, ki ji je kljub vsemu treba posvetiti nekaj vzgoje, saj drugače nima pomena. Zato se naslanjamo na Platona in ga sprašujemo po nekaterih odgovorih - prav ti pa so zelo zanimivi. Recimo: vzgoja, ki jo daje glasba, je zelo pomembna - pri njej namreč ritem in harmonija prodreta najgloblje $v$ dušo, jo najmočneje prevzameta in človeka naučita plemenitega vedenja - tako postane plemenit vsakdo, ki je pravilno vzgojen, kakor velja nasprotno za vsakogar, ki ni tako vzgojen (Platon 1976, 118-119).

Adamičeva filmska glasba je ločena od filma in hkrati njegova zaveznica. Njen pomen je $v$ tem, da daje filmu dodaten ritem in interpretacijo na tistih mestih, kjer morda zmanjka besed ali pa so popolnoma nepotrebne. Poslušajmo natančno sam začetek filma, naslovno pesem - temna, preteča, usodna in se izteče $v$ glasbo kočije, ki pelje $v$ Zapolje. In ni slučaj, da je prvi partiturni nastavek za tem posvečen podobi ženske/dekleta, ki poseda na zidu. Adamič ji nameni obratne tone kakor uvodnemu songu. Ta kontrapunktični, skoraj dur-mol element, zaokroža to partituro $v$ celoti. Trikotniško dogajanje med mladim učiteljem, žensko in oblastjo Adamič vedno podčrtava z glasbenimi pripombami, včasih krajšimi, včasih daljšimi. Vendar vedno umestnimi. Filmska glasba Idealista postane $s$ tem nekakšna zaveznica $v$ svetu nevidnih sil, $s$ katerimi je imel človek v svoji zgodovini vedno dobre odnose. Sprašujemo se lahko, zakaj bi se zdaj, v svetu norega kapitalističnega vrveža to spremenilo. Pravzaprav ni razloga, da bi se - in se prav zaradi tega tudi ne bo. Še vedno je mogoče namreč sanjati, upadi, idealizirati. Vendar imajo tudi sanje dve plati - samo vedeti moramo, na kateri strani smo $v$ tem trenutku. Dobro je, da vemo. Ni pa nujno.

17 Citirano po http://www.film-center.si/index.php?module=fdb\&op=film\&filmID=2056 (12. april 2018). 


\section{$1981-1995$}

Težko bi rekli, katero obdobje je bilo za Bojana Adamiča bolj izrazito. Vsekakor pa se njegove filmske partiture s časom ogibajo popularnim tonom in postajajo zrelejše, močnejše in hkrati s tem tudi prepoznavnejše. To desetletje je pričel z glasbo za TV film Manj strašna noč (1981, režija Andrej Stojan, literarno predlogo Aleksandra Gala je za film predelal Dimitrij Rupel, v glavni vlogi pa je nastopil Janez Vrhovec). Sledi glasba za film Boj na požiralniku (1982, režija Janez Drozg, v glavnih vlogah Bert Sotlar, Jerca Mrzel in Polde Bibič). Kar pa to obdobje zanesljivo zaznamuje, je film Butnskala (1985, režija Franci Slak, v glavnih vlogah Emil Filipčič, Marko Derganc-Dergi, Janez Hočevar-Rifle, Mila Kačič in Majolka Šuklje). Gre brez dvoma za izjemno devetdesetminutno parodijo in satiro na prepoznavne družbeno-politične trenutke tedanjega (in sedanjega) časa, zato lahko temu filmu in izredno domiselni partituri pripišemo kar »vsečasnost« in odlično komedijantstvo. Adamič je bil mojster humorne glasbene plati, kar je pravzaprav izredno redko. Omeniti moramo še filmsko partituro za zgodovinsko dramo Christophoros (1985, režija Andrej Mlakar, v glavnih vlogah Zvone Agrež, Urška Mlakar in Milena Zupančič) - film, ki sloni na naravnih, življenjskih, političnih in ideoloških nasprotjih.

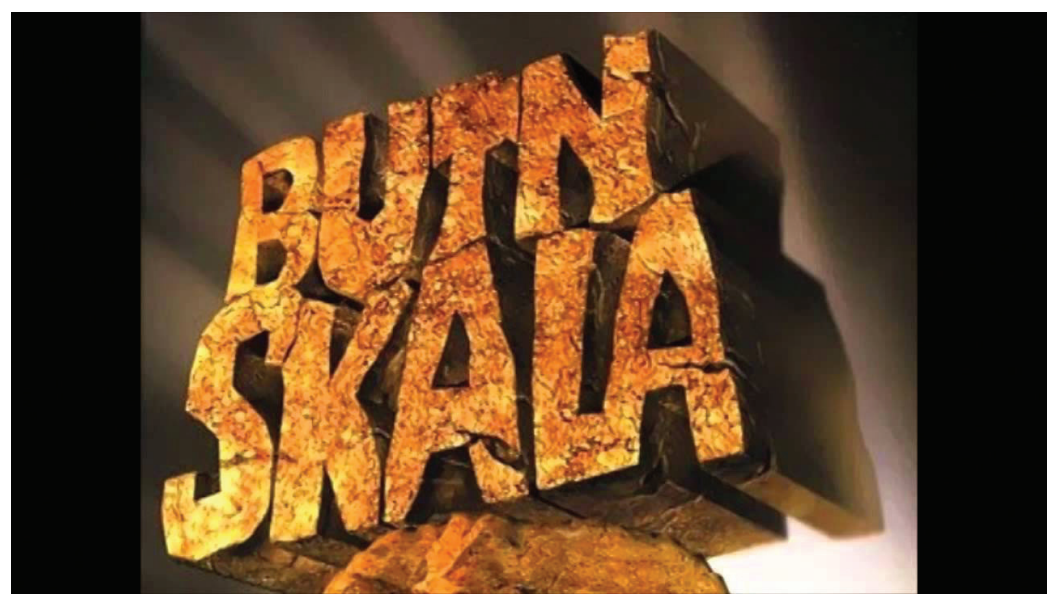

Slika 5 - Najava filma Butnskala (1985)

V tem času sta nastali tudi pomembna glasba za film Kavarna Astoria (1989, režija Jože Pogačnik, v glavnih vlogah Janez Hočevar-Rifle, Lidija Kozlovič in Branko Šturbej) ter njegova zadnja partitura: gre za 23-minutni kratki dokumentarni film z naslovom Neme podobe slovenskega filma (1995, režija Damjan Kozole). Ta film je pravzaprav arhivsko-dokumentarno gradivo, ki se prične skorajda v točki nič, torej tam, kjer je zibelka slovenske kinematografije - v Ljutomeru davnega leta 1905. Film je nekakšen hommage ob 90-letnici nastanke teh prvih po- 
dob, sicer pa gre za preglednik ključnih filmskih fragmentov iz obdobja slovenskega nemega filma vse tja do leta 1938. Scenarist tega filmskega projekta je bil Silvan Furlan.

\section{Butnskala (1985, režija Franci Slak) ali zgodba o uspešnem butanju z glavo}

Morda je to najbolj svojevrsten film, h kateremu je pristopil Adamič. $\checkmark$ vsej zgodovini njegovih partitur ga ni primera, kjer bi ponudil tako heterogeno glasbeno misel, kakor prav v tem filmu. Ker gre za komedijo, je jasno, da so $v$ partituri komični elementi - Adamič jih vselej doseže kot nekakšen glasbeni anti-element sliki. Ukvarja se predvsem s stilnimi drugačnostmi (komentarji), kar pomeni, da dramatičnost zamenja za lahkotnost, ironijo za pompoznosti in tragiko $s$ komičnostjo. Vendar je šel Adamič še nekoliko dlje - $v$ glasbeni jezik je ujel tudi enigmatičnost in grotesknost filmskih likov, ki se gibljejo (živijo, delujejo) v popolnoma »drugem « svetu, kakor bi pričakovali. Filmska glasba tako ne more biti interpretatorica dogajanja (čeprav bi lahko rekli, da mestoma prav to je), temveč mora vsebovati tiste druge elemente, ki jih slika ne izpolnjuje - recimo misel gledalca ob določenem prizoru ali pa komentar poanti, ki je bila izrečena kot na primer namig. Prav slednje je vsekakor v filmu Butnskala nekaj, kar deluje skoraj nenehno - predvsem v besedilnem svetu filma. Z nekakšno »montypythonsko« držo, zmedeno dinamiko in skrajno absurdnimi kombinacijami komentarjev filmske stekline $s$ solo glasbenimi vložki se Adamič spopada v dialogu s svojo glasbo in filmskim dogajanjem. Je zaletavanje z glavo $\checkmark$ skalo šport, ali pa le manever tistih, ki morajo (in želijo) poskusiti še kaj novega? Filmska partitura pospremi pravzaprav vsak »skok« z drugačno idejo, vse pa lepo pospravi v šopek ironije, s katero nenehno zabava, izpolnjuje vrzeli in poganja cirkus »butnskale« naprej. Adamič ponudi glasbene teme eminance, profesorja, Kralja, pa tudi določenim dejanjem, kot so vhod v tajne prostore, odhodi na sestanke, pa v »sprejemnico«; potem to, čemur rečejo v filmu »v kraju samem«, razkol med resničnim in sanjskim svetom. Prav tako je Valentinčič lik, ki se Adamičevi partituri poda kot dodatna nota, s katero razpolaga tudi Fanči - glasbena melodrama se vedno izpoje $v$ »duševni terapiji« zvočnega in glasbenega učinka, »levjega« skoka na glavo - seveda v skalo. Pridušeni zvok trobente pa resnično zalepi skupaj celotno ironijo.

Bojan Adamič je postavil odlične glasbene standarde $v$ pojmovanju filmske glasbe, ki je napolnjevala slovenske in mnoge druge filme $v$ času njegovega komponiranja. S svojim skorajda neproblematičnim glasbenim šarmom in izrednim občutkom za melodičnost je znal prisluhniti filmski podobi na način, kakor je to razumeti v najbolj opevanih filmih pretekle in polpretekle zgodovine. Njegova filmska glasba je hkrati sogovornica filmskih prigod, istočasno pa poudarja svojo avtonomnost in koncertnost. Kar nekaj delov filmskih partitur je samo- 
stojnih in zaokroženih glasbenih kompozicij in prav je, da se na njih tudi gleda tako. Tisto, kar želijo nekateri filmski kritiki pripisati glasbeni spremljavi, je pri Adamiču pravzaprav nemogoče definirati - njegova filmsko-glasbena govorica se giblje med filmom in glasbo po robu, na katerem je možno opazovati pravzaprav oboje: film kot umetnost slikovnega sporočila in glasbo kot umetnost slušnega polja. Če na tem mestu povzamemo misel Ludwiga van Beethovna, da je glasba višje razodetje kot vsa modrost in filozofija, ali izjavo Richarda Wagnerja, da bo glasba vedno ostala najvišja odrešujoča umetnost, saj le ona dokončno uresničuje to, kar ostale umetnosti samo nakazujejo: s svojo čisto, resno naravo preobrazi in prečisti vse, česar se dotakne, potem moramo postaviti Adamičeve filmske partiture med tiste, ki dajejo glasbeni umetnosti pečat (z)možnosti filmskega mišljenja. A tega slovenski filmski kritiki ne morejo ujeti v svojih lajnah o pomembnosti slikovne naracije.

\section{Čisto za konec}

Za komunikacijo zvok - glasba - gledalec ni nujno, da je vedno in samo zvočna. Lahko je postavljena kot suspenzija v film, torej nekakšna razredčina, ki jo moramo znati precediti. Če je bil torej Hitchcock mojster slikovnega suspenza, tistega, ki je vezan na filmsko podobo in naracijo, potem je tedaj ob njem stal drug mojster zvočnega suspenza: Bernard Herrmann. Kakor v tem času ob Hladniku - Adamič. Morda je bila to največja Adamičeva glasbena vloga v slovenskem filmu.

\section{Literatura}

Benveniste, Emile. 1966. Problèmes de linguistique générale. Pariz: Gallimard.

Derrida, Jacques. 1992. Before the Law.v: Acts of Literature. New York: Routledge. Janet, Pierre. 1928. L'Evolution de la mémoire et la notion du temps. Paris: Editions A. Chahine.

Ksenofan. 1963. „Umetnost lova«, V, 5-6. v: Xenophon Atheniensis: Anabasis: pohod $v$ notranjost. Kirova vzgoja. Ljubljana: Mladinska knjiga.

Lévi-Strauss, Claude. 1985. Oddaljeni pogled. Ljubljana: Studia Humanitatis.

Močnik, Rastko. 2006. Julija Primic v slovenski književni vedi. Ljubljana: Sophia.

Morelli, Giovanni. 2009. Kunstkritische Studien über italienische Malerei, Die Galerien zu München und Dresden. Leipzig.

Platon. 1976. Država. Ljubljana: DZS, knjiga III, 401d-e.

Platon. 1982. Zakoni. Maribor: Založba Obzorja, knjiga II., 655d.

Rotar, Braco. 1981. Govoreče figure. Ljubljana: Analecta.

Saussure, Ferdinand de. 1997. Predavanja iz splošnega jezikoslovja. Ljubljana: Studia Humanitatis. 
Mitja Reichenberg

Institut i akademija za multimedije (IAM)

Ljubljana, Slovenija

\section{FILMSKA MUZIKA I ZLATNE GODINE SLOVENAČKOG FILMA (2)}

Članak predstavlja partiture kompozitora Bojana Adamiča koje su bile namenjene kinematografskim slikama velikog ekrana, a zatim upozorava na nešto što slovenačka filmsko-muzička istorija uglavnom prećutkuje - da su nekada muziku za film stvarali kompozitori koji su muzičko-kompozitorsku struku poznavali, dok se filmskom muzikom danas, upravo zbog neretko niskog kvaliteta slovenačkog filma, često bave ljubitelji jednostavnih muzičkih invencija i efekata. Drugim rečima, njome se danas bave muzički nedovoljno obrazovani pojedinci s pedigreom zabavnog, populističkog i neproblematičnog žargona. Upravo u tom svetlu, želimo da o pojedinačnim partiturama intenzivnije razmislimo, jer je u takvom close up slušanju skriveno Adamičevo dublje promišljanje o samoj prirodi muzike, filma i, na kraju krajeva, slušaoca.

Ključne reči: Bojan Adamič, jugoslovenski film, filmografija, istorija filma, analiza

Mitja Reichenberg

Multimedia Institute and Academy

Ljubljana, Slovenia

FILM MUSIC AND THE GOLDEN AGE OF SLOVENIAN FILM (2)

The paper presents Bojan Adamič's scores intended for cinema films, while highlighting a fact usually missed in the Slovenian history of film music: in the past, music for film was made by composers knowledgeable in music composition, whereas nowadays film music is an arena for those keen on simple music inventions and effects, which is associated with the largely poor quality of recent Slovenian films. In other words, film music is currently practices by musically undereducated individuals with a background in an entertaining, populist and unchallenging jargon. It is in this light that the author analyzes in detail individual scores: close up listening reveals Adamič's deeper reflections on the nature of music, film and, ultimately, the audience.

Keywords: Bojan Adamič, Yugoslav film, filmography, cinematographic history, analysis 